\title{
Samowychowanie seksualne młodzieży w świetle literatury przedmiotu i badań własnych
}

\author{
Sexual Self-upbringing of Youth in Light \\ of the Literature of the Subject and Own Research
}

\begin{abstract}
ABSTRAKT
We współczesnej rzeczywistości społecznej można wyróżnić takie zjawiska i procesy, które wiq̨żq się z seksualnościq człowieka i jako takie moga rzutować na procesy (samo)wychowania w tym zakresie. W tej grupie można wymienić między innymi zmianę sposobów mówienia o seksualności i jej prezentowania w przestrzeni publicznej, zmianę obyczajowości seksualnej, komercjalizację czy supermarketyzację seksu.

Nie dokonujqc oceny zjawisk i procesów, których jest znacznie więcej niż powyżej wymienione, można stwierdzić, że współcześnie zachodzi wiele zmian społecznych i kulturowych, które przynajmniej w potencjalny sposób maja znaczenie dla procesu (samo)wychowania. W artykule przyięto tezę, że wobec wielości nowych procesów i zjawisk, w obliczu których dorasta współcześnie młodzież, samowychowanie seksualne stanowi istotny element wychowania młodego człowieka. W artykule przedstawiono istotę i znaczenie samowychowania, wskazano przesłanki uzasadniajqce potraktowanie seksualności

SPI Vol. 20,2017/2

ISSN 2450-5358

e-ISSN 2450-5366

DOI: 10.12775/SPI.2017.2.011

Raporty z badań
\end{abstract}


człowieka jako przedmiotu działalności samowychowawczej, zaznaczono również relację jaka zachodzi na linii wychowawca-samowychowanie seksualne. Na podstawie badań empirycznych zaprezentowano stosunek młodzieży do samowychowania seksualnego oraz w końcowej części artykułu ukazano potrzebę formacji młodzieży w kontekście samowychowania seksualnego.

\section{ABSTRACT}

In the modern social reality phenomena and processes may be distinguished which are connected with human sexuality and, as such, they may influence (self-) upbringing in this area. In this group we can enumerate, among others, the change of describing sexuality, the change of its presentation in public space, the change of sexual morals, commercialisation or sex super-marketing.

Not assessing the phenomena and processes, which are bigger in number than mentioned above, one may state with certainty that nowadays many ongoing social and cultural changes have at least a potential impact on the (self) upbringing process. The thesis that sexual self-upbringing stands for a crucial element of upbringing, due to the multitude of new processes and phenomena with which youth grow up with, has been adopted for the article. The core and the meaning of self-upbringing are presented in the article as well as the premises which reason why human sexuality is self-upbringing activity, and the relation in the area tutor-sexual self-upbringing. On the basis of empirical research, the attitude of the youth towards sexual self-upbringing is presented and, at the end of the article, the needs of youth formation in the context of sexual self-upbringing are provided.

\section{Wprowadzenie}

Współczesna rzeczywistość społeczna bywa w różny sposób oceniana pod kątem jej znaczenia dla edukacji seksualnej młodego pokolenia. Mówiąc w pewnym uproszczeniu, w opinii publicznej można dostrzec dwa przeciwstawne stanowiska. $Z$ jednej strony słyszy się głosy uznania, że nastają wreszcie czasy wolności i niezależności, swobody wyboru tego, kim chce się być i jak chce się żyć. $Z$ drugiej 
strony można usłyszeć głosy przeciwne, mówiące że współczesna rzeczywistość społeczna w coraz większym stopniu pozbawiana jest wartości, zasad moralnych, że nastają czasy aksjologicznego chaosu, w którym rozwój młodzieży jest zagrożony.

Literatura naukowa, między innymi z zakresu socjologii, psychologii, pedagogiki, dostarcza opisu i interpretacji wielu zjawisk i procesów, które są symptomatyczne dla początku XXI wieku, a które, przynajmniej w potencjalny sposób, mają znaczenie dla procesu wychowania. Należą do nich między innymi supermarketyzacja czy makdonaldyzacja życia. Można także wyróżnić we współczesnej rzeczywistości społecznej takie zjawiska i procesy, które wiążą się z seksualnością człowieka i jako takie mogą rzutować na procesy (samo)wychowania w tym zakresie. W tej grupie można wymienić między innymi zmianę sposobów mówienia o seksualności, jej prezentowania w przestrzeni publicznej, zmianę obyczajowości seksualnej, komercjalizację czy supermarketyzację seksu.

Nie dokonując oceny zjawisk i procesów, których jest znacznie więcej niż powyżej wymienione, można stwierdzić, że współcześnie zachodzi wiele zmian społecznych i kulturowych, które w przynajmniej potencjalny sposób mają znaczenie dla procesu (samo)wychowania. W artykule przyjęto tezę, że wobec wielości nowych procesów i zjawisk, w obliczu których dorasta współcześnie młodzież, samowychowanie seksualne stanowi istotny element wychowania młodego człowieka. W artykule zostaną przedstawione istota i znaczenie samowychowania, wskazane będą przesłanki uzasadniające traktowanie seksualności człowieka jako przedmiotu działalności samowychowawczej, zaznaczona zostanie również relacja jaka zachodzi na linii wychowawca-samowychowanie seksualne. $\mathrm{Na}$ podstawie badań empirycznych zaprezentowany zostanie stosunek młodzieży do samowychowania seksualnego oraz w końcowej części artykułu ukazane zostaną wybrane formy samowychowania seksualnego oraz potrzeba formacji młodzieży w tym kontekście.

\section{Istota i znaczenie samowychowania}

Samowychowanie to „samorzutna praca człowieka nad ukształtowaniem własnego poglądu na świat, własnych postaw, cech charakteru i własnej osobowości - stosownie do założonych kryteriów, wzorów 
oraz ideałów"1. Inaczej mówiąc, jest to proces świadomego kierowania przez osobę własnym postępowaniem, który to proces polega na ciaggym poddawaniu autokontroli własnych zachowań. Samowychowanie stanowi proces kierowania własnym rozwojem w celu osiągnięcia mniej lub bardziej uchwytnego wzorca osobowego ${ }^{2}$.

Pierwszą z istotnych cech samowychowania jest to, że wspólwystępują w nim dwa procesy - proces kierowania własnym rozwojem oraz proces zmian osobowości podmiotu, który podejmuje samowychowanie. Ponadto źródłem samowychowania jest przyjęcie wzoru, ideału, który będzie się zamierzało osiągnąć. W kontekście psychologicznym można powiedzieć, że samowychowanie składa się z szeregu procesów psychicznych - np. samopoznania, samooceny, samokontroli - które skutkują zmianami w sferze emocjonalno-motywacyjnej osobowości. Samowychowanie polega więc na wywołaniu lub wzbudzeniu w sobie samym procesów intelektualnych, poznawczo-emocjonalnych i wolicjonalnych. Wreszcie można powiedzieć, że w wyniku prowadzonego procesu samowychowania następuje seria zmian w osobowości podmiotu, a osobowość ta przechodzi od stanu wyjściowego, poprzez stany pośrednie aż do udoskonalonego stanu finalnego ${ }^{3}$.

Tak rozumiany proces samowychowania składa się z siedmiu etapów. Pierwszym jest idealizacja - polega na przyjęciu określonego ideału/wzoru osobowościowego. Drugi etap stanowi samopoznanie - polega na ukształtowaniu sobie obrazu własnej osoby pod wybranym względem. W jego efekcie następuje trzeci etap - samoocena. Jej dokonanie jest możliwe dzięki porównaniu własnej osoby z przyjętym na pierwszym etapie wzorem. Czwarty etap polega na wzbudzeniu w sobie aspiracji perfekcjonistycznych, a zatem przeżyciu motywacji do dokonania określonych zmian we własnej osobowości. Decyzje samorealizacyjne to piąty etap procesu samowychowania. W jego toku osoba ustala zadania i wymagania, którym chce sprostać, aby osiągnąć wybrany przez siebie wzór. Gdy to zostanie zaplanowane, następuje szósty etap - działania samowychowawcze. Siódmy, ostatni etap, stanowi samoocena końcowa,

1 W. Okoń, Nowy stownik pedagogiczny, Warszawa 2007, s. 366.

2 A.J. Sowiński, Samowychowawcza aktywnośc mtodzieży, Szczecin 1990, s. 8.

3 A.J. Sowiński, Rozważania o samowychowaniu, Szczecin 1997, s. 26-28. 
podczas której osoba dokonuje samooceny swojego postępowania i uzyskanych dotąd efektów swoich działań4.

W odniesieniu do samowychowania seksualnego szczególnie interesująca wydaje się koncepcja tego zjawiska w ujęciu niemieckiego pedagoga Fryderyka Wilhelma Foerstera. Jego zdaniem okres, w którym człowiek podejmuje trud samowychowania poprzedza stan bezcharakterności, tj. stan, w którym porządek funkcjonowania sfery duchowej i zmysłowej człowieka jest zaburzony. Okres ten cechuje egocentryczne nastawienie człowieka, w którym uznaje on za kluczowe własne prawa i potrzeby. Można więc powiedzieć, że kieruje jego działaniem natura. Początkiem i warunkiem pracy nad doskonaleniem charakteru, jak twierdzi F.W. Foerster, jest uznanie, że natura i osoba nie są pojęciami tożsamymi ${ }^{5}$. Wydaje się, że rozróżnienie to - na działanie natury i działanie osoby - jest szczególnie przydatne $\mathrm{w}$ analizie istoty procesu samowychowania seksualnego. Pożądanym stanem rzeczy w kwestii (samo)wychowania seksualnego jest osiągnięcie stanu integracji, a więc harmonijnego współdziałania wszystkich wymiarów osoby. Aby jednak taki stan mógł zostać osiągnięty, konieczne jest podjęcie trudu samowychowania. Konieczne jest osiągnięcie punktu, w którym działanie naturalne, stanie się działaniem osobowym, a wiec spójnym z osobowym charakterem człowieka. Konieczność ta wynika z założenia o osobowej naturze człowieka. W tym kontekście natura nie stoi w opozycji do osoby. Naturalne działanie człowieka to działanie osobowe.

Samowychowanie odgrywa ważną rolę w życiu człowieka, szczególnie w okresie dorastania i wczesnej młodości. Wydaje się, że kontrolowanie własnego rozwoju i zachowania oraz kierowanie nimi w świadomy sposób jest konicznym elementem dojrzałego i odpowiedzialnego życia. Samowychowanie podejmowane w okresie młodości jest koniecznym przygotowaniem do samodzielnego, świadomego i odpowiedzialnego podejmowania decyzji w okresie dorosłości. Wybór specjalizacji zawodowej, miejsca pracy, usamodzielnienie psychiczne i finansowe od rodziny pochodzenia, założenie własnej rodziny - wszystkie te i wiele innych sytuacji typowych dla okresu

4 Tamże, s. 28-29.

5 E. Smołka, Filozofia ksztattowania charakteru. Fryderyka Wilhelma Foerstera teoria wychowania w świetle zatożeń personalizmu chrześcijańskiego, Tychy 2005, s. 122-123. 
dorosłości wymagają poznania samego siebie, dokonania samooceny, wyboru, poniesienia konsekwencji i wyciągnięcia wniosków na przyszłe działanie, a więc tych wszystkich umiejętności, które są kształtowane $\mathrm{w}$ procesie samowychowania ${ }^{6}$. Inaczej mówiąc, dla osoby nieposiadającej doświadczenia samowychowania dorosłość może się wiązać z bolesnym doświadczeniem błędnych wyborów, rozczarowań i niezrozumienia. W takim kontekście samowychowanie jawi się jako konieczne przygotowanie do dorosłego, odpowiedzialnego życia.

Samowychowanie seksualne stanowi szczegółowy rodzaj samowychowania jako takiego. Aby jednak zasadnie o nim mówić, należy odnieść się do kategorii seksualności jako przedmiotu działalności samowychowawczej.

\section{Seksualnośćc człowieka przedmiotem działalności samowychowawczej}

Istnieje wiele definicji seksualności człowieka. Najogólniej można dokonać ich podziału na dwie grupy. Pierwszą stanowią definicje wąskie, funkcjonalne, które odnoszą się do konkretnych aktywności i zachowań seksualnych ${ }^{7}$. Ich przykładem jest definicja Johna Bancrofta, według której

seksualność stanowi aspekt jego [człowieka - przyp. E.R.] kondycji przejawiający się w postaci pożądania lub pragnienia, towarzyszących im fizjologicznie zdeterminowanych odpowiedzi seksualnych i zachowań prowadzących do orgazmu lub przynajmniej do sprawiającego przyjemność podniecenia, występujących często między dwojgiem ludzi, lecz nierzadko także praktykowanych samotnie ${ }^{8}$.

Drugą grupę stanowią definicje szerokie. Ujmują one „wszystkie aspekty cielesne i zachowania człowieka związane z płcią i seksem". W tym nurcie mieszczą się definicje seksualności, które uwzględniają jej wielowymiarowy charakter oraz wzajemne relacje i zależności

6 Por. A.J. Sowiński, Samowychowawcza aktywnośc mtodzieży, dz. cyt., s. 8-9.

7 Z. Izdebski, Seksualność Polaków na początki XXI wieku. Studium badawcze, Kraków 2012, s. 49.

8 J. Bancroft, Seksualność człowieka, tłum. R. Śmietana, Wrocław 2011, s. 19.

9 A.S. Reber, E.S. Reber, Stownik psychologii, tłum. B. Janasiewicz-Kruszyńska, Warszawa 2000. Podaję za: Z. Izdebski, Seksualność Polaków na początku XXI wieku, dz. cyt., s. 49. 
pomiędzy ludźmi. W tym też kontekście seksualność bywa utożsamiana z miłością, która stanowi „najbardziej istotny, dyskursywny, kulturowy wymiar seksualności. A zarazem - jak twierdził José Ortega y Gasset - jedyną drogę do poznania głębokiej natury człowieka" ${ }^{10}$.

Samowychowanie ma sens w odniesieniu do rzeczywistości, na którą człowiek ma wpływ. Wydaje się, że w wąskim, funkcjonalnym rozumieniu seksualności nie ma na nie miejsca. Jeśli jest możliwe, to nie jest ono postrzegane jako coś korzystnego dla rozwoju osoby. Odmiennie sytuacja wygląda w odniesieniu do szeroko rozumianej seksualności jako wielopłaszczyznowej sfery życia, złączonej nierozdzielnie ze wszystkimi innymi wymiarami człowieka - fizycznym, psychicznym czy duchowym. Można więc powiedzieć, że warunkiem sine qua non podjęcia samowychowania seksualnego jest uznanie, że seksualność stanowi złożony i wielowymiarowy aspekt osoby i złączone jest nierozerwalnie ze wszystkimi jej wymiarami. Definicja, która odpowiada temu wymogowi, i która została przyjęta w artykule, przyjmuje brzmienie:

seksualność jest podstawowym elementem bycia człowiekiem przez całe życie, obejmującym seks, płciową identyfikację i role, orientację seksualną, erotyzm, pożądanie, intymność i reprodukcję. Seksualność jest doświadczana i wyrażana w myślach, fantazjach, przeżyciach, przekonaniach, wartościach, zachowaniach, rolach i związkach. Seksualność powstaje na skutek interakcji czynników biologicznych, psychologicznych, społecznych, ekonomicznych, politycznych, kulturowych, etycznych, prawnych, historycznych, religijnych i duchowych ${ }^{11}$.

Konsekwencją przyjęcia takiej podstawy wobec samowychowania seksualnego jest założenie, że jego celem jest osiągnięcie seksualnej integracji. Integracja seksualna młodzieży stanowi zaś wynik procesu harmonizowania wszystkich wymiarów życia osoby związanych z seksualnością. Jej fundamentem jest uznanie złożonej, wielowymiarowej istoty seksualności powiązanej z całym życiem człowieka. Integracja seksualna jest wynikiem prowadzenia świadomego procesu samowychowania zmierzającego do scalenia wszystkich wymiarów osoby związanych z seksualnością według właściwej im hierarchii. Na integrację seksualną składa się sześć komponentów: przyjmowanie pozytywnej

10 Z. Izdebski, Seksualność Polaków na początku XXI wieku, dz. cyt., s. 49.

11 M. Laphimon, A Glossary of Terms in Gender and Sexuality, Seul 2005, podaję za: Z. Lew-Starowicz, Psychospoteczne podstawy seksualności, w: Podstawy seksuologii, red. Z. Lew-Starowicz, V. Skrzypulec, Warszawa 2010, s. 25. 
i integralnej wizji seksualności człowieka, akceptacja tożsamości płciowej i związanych z nią ról, dojrzałość biologiczna, dojrzałość emocjonalnego wymiaru seksualności, jej psychizacja i humanizacja.

$\mathrm{O}$ ile na proces osiągania dojrzałości biologicznej w aspekcie seksualności człowiek nie ma wpływu, o tyle pozostałe komponenty integracji seksualnej wydają się pozostawać w zakresie oddziaływań osoby. Szczególnie zaś istotnym w kontekście samowychowania seksualnego elementem integracji seksualnej jest jej humanizacja. Pojęcie to, przyjęte za Zdzisławem Chlewińskim ${ }^{12}$, oznacza włączenie seksualności w całość życia człowieka, uczynienie jej spójnym ze wszystkimi innymi obszarami wymiarem życia człowieka.

Jak wskazuje nazwa, samowychowanie seksualne jest osobistą, samodzielną aktywnością człowieka. W procesie samowychowania pośredni udział mają jednak również wychowawcy. Ich rolą jest między innymi wskazywanie wychowankom możliwych metod i technik pracy samowychowawczej, by w momencie, gdy ich seksualność będzie wymagała podjęcia wysiłków samowychowawczych, młodzi ludzie byli do tego zadania przygotowani. W kolejnym ustępie szerzej zostanie zarysowana rola wychowawców w procesie samowychowania seksualnego młodzieży.

\section{Wychowawcy a samowychowanie seksualne młodzieży}

W literaturze pedagogicznej można spotkać różne ujęcia związku wychowania i samowychowania. Istnieje zgoda co do tego, że związek wychowania i samowychowania nie ma charakteru koniecznościowego. Oznacza to, że nie każde wychowanie prowadzi automatycznie do samowychowania ${ }^{13}$. W kontekście samowychowania seksualnego właściwe wydają się dwa podejścia. Pierwsze mówi o tym, że samowychowanie $\mathrm{w}$ stosunku do wychowania jest zjawiskiem wtórnym. Pojawia się bowiem jako rezultat wcześniejszych procesów wychowawczych ${ }^{14}$. Drugie stanowisko, bynajmniej nie sprzeczne

12 Zob. Z. Chlewiński, Seks i autorealizacja (1),„W Drodze”1978, t. 6, nr 2(54), s. $13-20$.

13 A.J. Sowiński, Samowychowanie w interpretacji pedagogicznej, Szczecin 2006, s. 37.

14 Z. Matulka, Samowychowanie, w: Wprowadzenie do pedagogiki dorostych, red. T. Wujek, Warszawa 1992, s. 148. 
z pierwszym, mówi o tym, że samowychowanie stanowi konieczny składnik wychowania. Tak więc samowychowanie jest elementem, ważnym aspektem procesu wychowania ${ }^{15}$.

Potrzeba realizacji samowychowania jest związana $\mathrm{z}$ dynamiką rozwoju psychoseksualnego człowieka. Ten zaś nabiera intensywności w okresie dorastania. Dopiero w tym okresie życia człowieka ważne jest wychowywanie własnej, intensywnie rozwijającej się seksualności. Aby jednak uruchomienie procesów samowychowawczych na tym etapie życia było możliwe, konieczne jest przygotowanie do niech młodzieży w procesie wychowania na wcześniejszych etapach życia. W tym sensie samowychowanie stanowi owoc, rezultat wychowania. Wychowanie powinno być więc wychowaniem do samowychowania. Ma to swoje uzasadnienie w jeszcze jednym fakcie. Seksualność jest intymną sferą życia. W zależności od osobistych uwarunkowań oraz od bliskości relacji młodego człowieka $\mathrm{z}$ rodzicami i wychowawcami różna może być otwartość wychowanka na oddziaływania wychowawcze w zakresie seksualności. Ingerencja wychowawcza w tak intymną sferę życia może się okazać w niektórych przypadkach niemożliwa. Zasadne wydaje się w tym aspekcie przytoczenie słów papieża Franciszka, który w odniesieniu do aktualnej sytuacji rodzin powiedział, że ,jesteśmy powołani do kształtowania sumień, nie zaś domagania się, by je zastępować"16. W odniesieniu do (samo)wychowania seksualnego te słowa o tyle są ważne, że w pewnym momencie życia wychowanka wychowawcy tracą możliwość decydowania o jego zachowaniach i przekonaniach. Jeśli na wcześniejszym etapie życia nie będzie miało miejsca kształtowanie sumień wychowanków, na nic zdadzą się próby ich zastąpienia w okresie dorastania. Jak wynika z badań, nie do rzadkości należą sytuacje, że rodzice rozpoczynają wychowywanie seksualne swoich dzieci dopiero w momencie, kiedy te inicjują życie seksualne. Zapewne zakazy lub moralizowanie, które mogą w takim wypadku stanowić próbę wychowywania seksualnego, choć troską powodowane, będą bardziej próbą zastąpienia sumienia młodego człowieka niż jego kształtowaniem.

15 A.J. Sowiński, Samowychowanie w interpretacji pedagogicznej, dz. cyt., s. 36.

16 Franciszek, Posynodalna adhortacja apostolska „Amoris laetitia”, Kraków 2016, s. 37. W adhortacji apostolskiej zdanie to odnosi się do oddziaływań Kościoła, wydaje się jednak, że można to samo twierdzenie zastosować do kwestii (samo)wychowania seksualnego. 
W przypadku seksualności wydaje się więc zasadne przygotowywać młodego człowieka w procesie wychowania do podjęcia wysiłku samowychowania. Środek ciężkości przechodzi w takim ujęciu wraz z kolejnymi etapami rozwoju psychoseksualnego człowieka od wychowania do samowychowania. W okresie dzieciństwa dominuje wychowanie seksualne, w okresie dojrzewania wychowanie i samowychowanie seksualne przeplatają się, by z kolejnymi latami dorastania rola samowychowania stała się dominująca.

By taki model dochodzenia do podjęcia wysiłku samowychowania seksualnego mógł się stać możliwy, konieczne jest, aby rodzice i inni wychowawcy uczynili samowychowanie przedmiotem własnego zainteresowania. W tym miejscu zostaną poruszone dwie kwestie. Pierwsza dotyczy rodziców, druga obecności kategorii samowychowania seksualnego w podstawie programowej przedmiotu Wychowanie do życia w rodzinie (WDŻ). Panuje w literaturze przedmiotu zgoda co to tego, że rola rodziców w wychowaniu dzieci, również wychowaniu seksualnym, jest bardziej znacząca niż innych wychowawców. Interesujące wydaje się zatem to, co rodzice młodzieży sądzą o kwestii samowychowania. Można bowiem przyjąć hipotezę, że stosunek rodziców do samowychowania nie jest obojętny i wpływa na to, jaki stosunek do samowychowania przejawiać będą ich dzieci.

Z przeprowadzonych przez autorkę artykułu badań wynika ${ }^{17}$, że zdecydowana większość ze 109 badanych par rodziców docenia znaczenie samowychowania w życiu człowieka. Samowychowanie i samodoskonalenie nie są pojęciami tożsamymi, jednak można zaryzykować twierdzenie, że przekonanie rodziców o konieczności podejmowania pracy nad sobą, aby być coraz lepszym rodzicem, jest związane z samowychowaniem. Zdecydowana większość rodziców deklarowała, że jest to bliskie im przekonanie. Dane te przedstawione zostały w tabeli 1 .

17 Badania zostały przeprowadzone pod kierownictwem prof. dr hab. Zdzisława Kroplewskiego i stanowiły część pracy nad rozprawą doktorską zatytułowaną Personalistyczna orientacja wychowawcza rodziców a integracja seksualna mtodzieży. Badania empiryczne. Grupę badawczą stanowiło 109 rodzin: oboje rodziców i dziecko w wieku 17-20 lat. Badania zostały przeprowadzone metodą sondażu diagnostycznego, $\mathrm{z}$ wykorzystaniem dwóch autorskich kwestionariuszy, na przełomie 2014 i 2015 roku na terenie województwa zachodniopomorskiego. 


\begin{tabular}{|l|c|c|c|c|}
\hline \multirow{2}{*}{$\begin{array}{c}\text { Czy jesteś } \\
\text { przekonany(a) } \\
\text { o konieczności } \\
\text { podejmowania } \\
\text { pracy nad sobq, aby } \\
\text { być coraz lepszym } \\
\text { rodzicem? }\end{array}$} & N & $\%$ & N & $\%$ \\
\cline { 2 - 5 } & 48 & 44,04 & 37 & 33,94 \\
\hline Tak & 51 & 46,79 & 47 & 43,12 \\
\hline Raczej tak & 9 & 8,26 & 20 & 18,35 \\
\hline Trudno powiedzieć & 0 & 0,00 & 4 & 3,67 \\
\hline Raczej nie & 1 & 0,92 & 1 & 0,92 \\
\hline Nie & & & & \\
\hline
\end{tabular}

Tabela 1.

Przekonanie rodziców o konieczności podejmowania pracy nad sobq, aby być coraz lepszym rodzicem

Źródło: badania własne

Ponad połowa badanych rodziców $(60,66 \%)$ przyznała, że pracę nad samym sobą powinien podejmować każdy człowiek. $Z$ wyrażonym przez większość badanych rodziców przekonaniem, że każdy człowiek powinien dążyć do doskonałości, korespondują odpowiedzi udzielone na pytanie o to, czy badani rodzice we własnym życiu starają się doskonalić swój charakter tak, aby być lepszymi rodzicami. Ogółem 83,94\% badanych rodziców podejmuje samowychowanie, nie robi tego w sumie $2,75 \%$. Ponadto $88,07 \%$ kobiet i $79,81 \%$ mężczyzn przyznało, że podejmowanie pracy nad sobą każdego dnia jest koniecznym warunkiem rozwoju człowieka. Przykład osobisty rodziców w zakresie podejmowania trudu codziennej pracy nad sobą i ich przekonanie o potrzebie takiej aktywności mogą stanowić cenną pomoc i źródło motywacji dla dzieci, także w zakresie samowychowania w odniesieniu do własnej seksualności.

Większa część badanych rodziców żywiła przekonanie, że popęd seksualny można kontrolować (89,91\% kobiet i 85,32\% mężczyzn). Przeciwnego zdania było jedynie 4,59\% kobiet i 7,33\% badanych mężczyzn. Wynik ten jest o tyle ważny, że seksualność, jak zostało zaznaczone, może być różne definiowana. Wąskie ujęcie seksualności, według którego jest ona rozumiana głównie na sposób biologiczny, wykluczałoby możliwość i potrzebę podejmowania samowychowania seksualnego. Wynik uzyskany w badanej grupie pozwala przyjąć, że przejawiane rozumienie seksualności przez rodziców współgra z możliwością i potrzebą samowychowania w tym zakresie. 

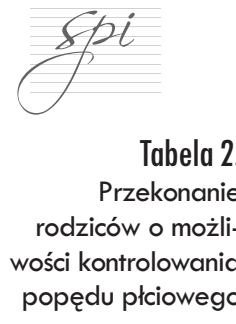

\begin{tabular}{|l|c|c|c|c|}
\hline \multirow{2}{*}{$\begin{array}{l}\text { Czy istnieje możliwość } \\
\text { kontrolowania popędu } \\
\text { płciowego? }\end{array}$} & \multicolumn{2}{|c|}{ Matki } & \multicolumn{2}{c|}{ Ojcowie } \\
\cline { 2 - 5 } & $\mathbf{N}$ & $\%$ & $\mathbf{N}$ & $\%$ \\
\hline $\begin{array}{l}\text { A - zdecydowanie tak, } \\
\text { jest on podporzqqdkowa- } \\
\text { ny woli osoby }\end{array}$ & 67 & 61,47 & 43 & 39,45 \\
\hline $\begin{array}{l}\text { B- raczej tak, choć jest } \\
\text { to trudne, a czasem } \\
\text { może być niemożliwe }\end{array}$ & 31 & 28,44 & 50 & 45,87 \\
\hline $\begin{array}{l}\text { C-nie mam zdania } \\
\text { D- raczej nie, popęd } \\
\text { wynika z naturalnego } \\
\text { działania organizmu, na } \\
\text { który nie mamy wpływu, } \\
\text { więc nie można tego } \\
\text { kontrolować }\end{array}$ & 6 & 5,50 & 8 & 7,34 \\
\hline $\begin{array}{l}\text { E- zdecydowanie nie, } \\
\text { jest to silne, naturalne } \\
\text { działanie biologiczne }\end{array}$ & 0 & 0,00 & 2 & 1,83 \\
\hline
\end{tabular}

Źródło: badania własne

$\mathrm{Z}$ analizy przytoczonych danych nasuwa się wniosek, że w badanej grupie rodziców samowychowanie stanowi ważny element własnej życiowej aktywności. Pogłębione analizy tego zagadnienia wymagają zbadania czy istnieje zależność pomiędzy przekonaniami i działaniami związanymi z samowychowaniem rodziców a podejmowaniem tej aktywności przez dzieci. W badanej grupie stwierdzono, że istnieje istotna statystycznie zależność ( $\mathrm{p}=000523)$ pomiędzy podejmowaniem przez kobiety codziennych starań o to, by być coraz lepszymi matkami a podejmowaniem samowychowania seksualnego przez młodzież. Podejmowanie aktywności samowychowawczej przez matki sprzyja podejmowaniu samowychowania seksualnego przez młodzież. Wyniki te zostały przedstawione w wykresie 1. 
Wykres 1.

Podejmowanie pracy nad soba, aby być coraz lepsza matka a podejmowanie samowychowania seksualnego przez młodzież

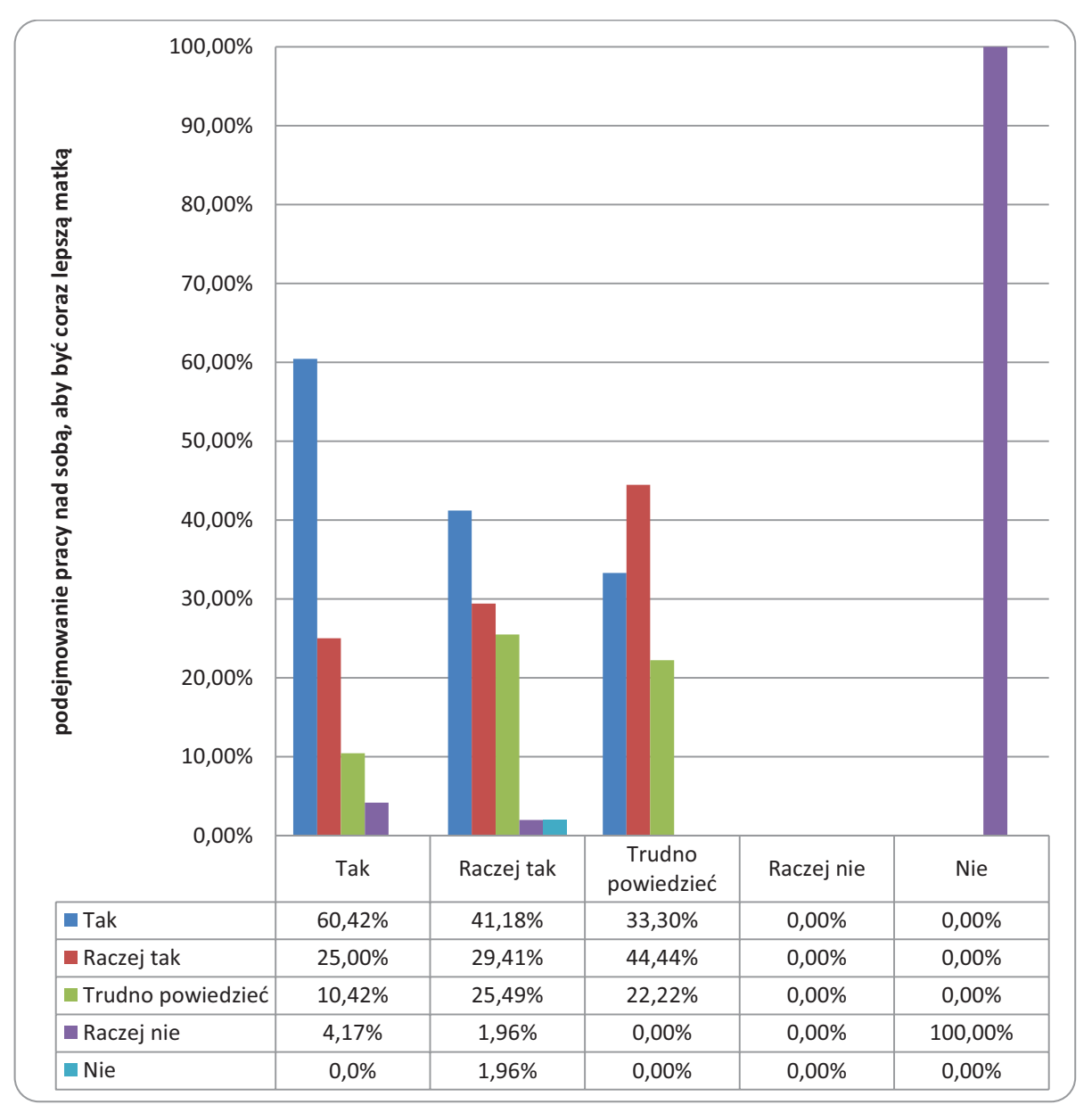

Źródło: badania własne

Podobnie sytuacja wygląda w przypadku zależności pomiędzy podejmowaniem aktywności samowychowawczej przez ojców a podejmowaniem samowychowania przez dzieci. Również w tym wypadku stwierdzono istnienie istotnej statystycznie zależności $(\mathrm{p}=000720)$. Wynik ten obrazuje wykres 2 . 


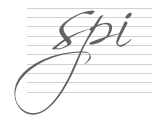

\section{Wykres 2.}

Podejmowanie pracy nad sobq, aby być coraz lepszym ojcem a podejmowanie samowychowania seksualnego przez młodzież

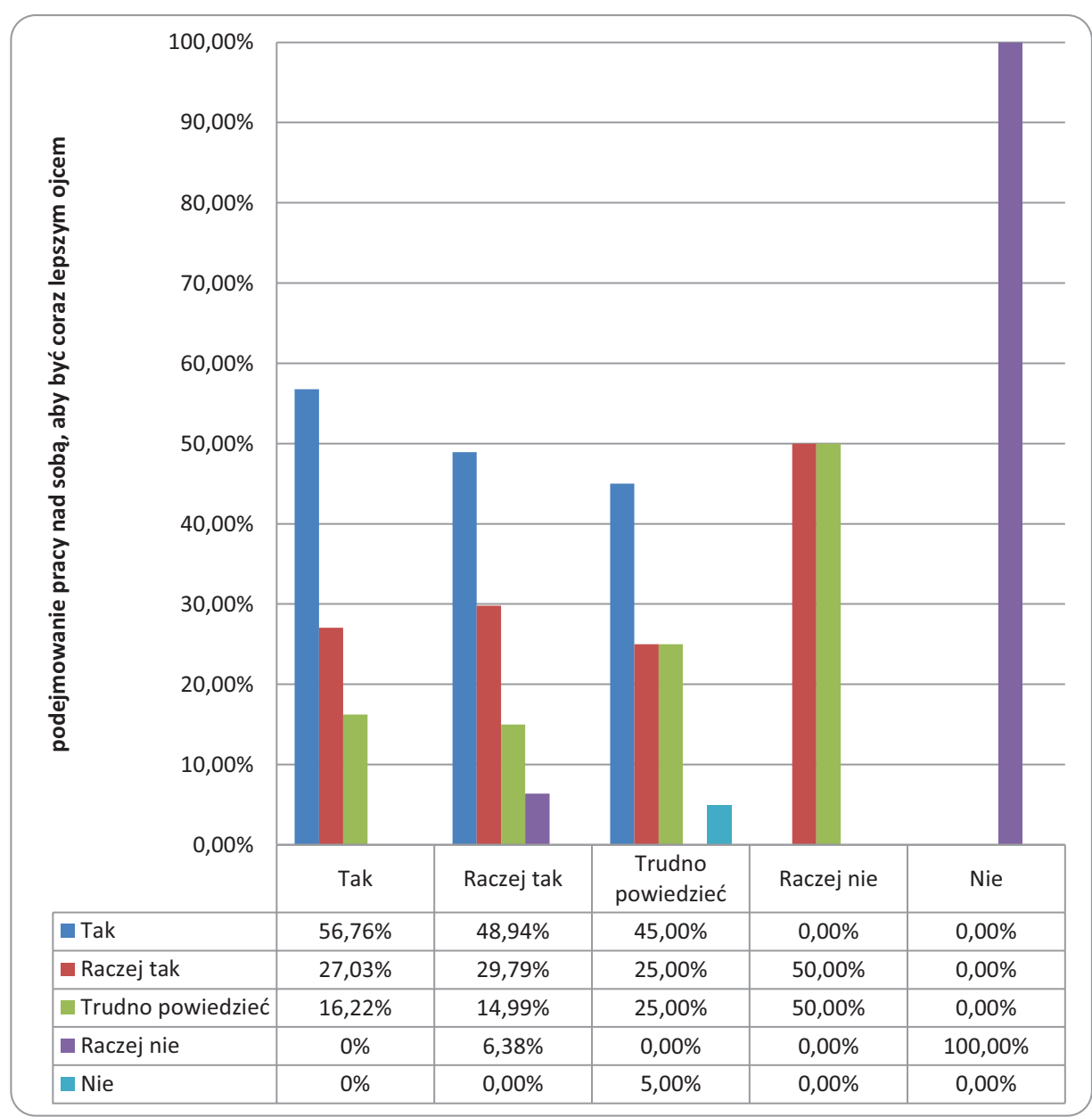

Źródło: badania własne

Druga kwestia wiązana $\mathrm{z}$ rolą wychowawców w procesie samowychowania seksualnego dotyczy tego, jak wychowawcy inni niż rodzice odnoszą się do kwestii samowychowania. Nie przeprowadzono jak dotąd badań empirycznych, które odpowiadałyby na pytanie o to, jak do samowychowania ustosunkowują się nauczyciele prowadzący przedmiot Wychowanie do życia w rodzinie. Można zresztą 
powątpiewać czy osobisty stosunek do tej kwestii ma znaczenie dla stosunku wobec samowychowania wychowanków uczestniczących w tych zajęciach, tak jak miało to miejsce w przypadku rodziców. Ważne jest natomiast czy program Wychowania do życia w rodzinie zawiera $\mathrm{w}$ swojej treści kwestie związane $\mathrm{z}$ samowychowaniem seksualnym. Dokonawszy analizy podstawy programowej zatwierdzonej przez Ministerstwo Edukacji Narodowej pod tym kątem, można stwierdzić ogólnie, że kategoria samowychowania seksualnego jest w nich obecna, ze szczególnym nasileniem na III etapie edukacyjnym, co wydaje się uzasadnione z perspektywy dynamiki rozwoju psychoseksualnego człowieka.

W tym miejscu zostaną przytoczone fragmenty podstawy programowej Wychowania do życia w rodzinie, w których mowa jest o samowychowaniu. Na II etapie edukacyjnym 13. treść nauczania przyjmuje brzmienie „Odpowiedzialność za własny rozwój; samowychowanie”. W programie nauczania uczniów IV-VI klas jest to jedyne miejsce, w którym problematyka ta zostaje podjęta. Więcej kwestii związanych $\mathrm{z}$ samowychowaniem seksualnym pojawia się w dokumentach odnoszących się do III etapu edukacyjnego. Jako jeden $\mathrm{z}$ celów kształcenia wymienia się „podejmowanie wysiłku samowychowawczego zgodnie z uznawanymi normami i wartościami”. Ponadto w zalecanych warunkach i sposobach realizacji podstawy programowej wskazuje się, że do zadań szkoły należy w szczególności „stymulowanie procesu samowychowania”. To zadanie szkoły jest wymienione jako pierwsze $\mathrm{z}$ dziewięciu właściwych dla III etapu edukacyjnego. Ponadto, jak zostało zaznaczone powyżej, kwestia samowychowania seksualnego jest wpisana w integralne rozumienie seksualności człowieka. Te kwestie również są obecne w podstawie programowej WDŻ (II i III cel kształcenia). $\mathrm{Na}$ IV etapie edukacyjnym samowychowanie seksualne nie jest ani razu wymienione wprost, jednak można założyć, że problematyka ta stanowi element 8. treści nauczania „Istota seksualności człowieka i jej aspekty. Integracja seksualna" ${ }^{18}$.

18 Wszystkie cytaty z podstawy programowej przedmiotu Wychowanie do życia w rodzinie pochodzą z: Podstawa programowa przedmiotu Wychowanie do życia w rodzinie. II etap edukacyjny: klasy IV-VI, <https://men.gov.pl/ wp-content/uploads/2011/02/4i.pdf> [dostęp: 9.10.2016]. 
Z przytoczonych powyżej refleksji wynika, że kategoria samowychowania seksualnego jest obecna $w$ rodzinach objętych badaniami empirycznymi oraz $\mathrm{w}$ podstawie programowej Wychowania do życia w rodzinie ( $\mathrm{z}$ różnym natężeniem na poszczególnych etapach edukacyjnych). Oprócz szkoły i rodziny, wśród ważnych oddziaływań (wychowawczych) można jednak wymienić te płynące z popularnych wśród młodzieży mediów. Wydaje się, że w tym przypadku samowychowanie seksualne jest kategorią nieobecną, a jeśli obecną - to z pewnością nie w tzw. głównym nurcie. Dokonania badawcze $\mathrm{z}$ zakresu socjologii i pedagogiki pozwalają na przyjęcie twierdzenia, że znaczna część treści obecnych w tychże mediach nie służy formacji młodego pokolenia i podejmowaniu wysiłków samowychowania seksualnego. Ze względu jednak na obszerność tego zagadnienia, wątek ten nie zostanie w artykule rozwinięty.

Rola wychowawców w procesie samowychowania seksualnego młodzieży jest podwójna. $Z$ jednej strony zadaniem wychowawców jest ukazanie młodzieży potrzeby wychowywania własnej seksualności, z drugiej zaś - ukazanie możliwych dróg realizacji tego wychowania. Oba działania wychowawców powinny być podejmowane od najwcześniejszych lat życia, tak by dla wchodzącego w okres dojrzewania młodego człowieka samowychowanie nie było narzuconym odgórnie obowiązkiem krępującym jego swobodę, lecz naturalnie rozpoczynającym się procesem. Aby uprawdopodobnić taki bieg zdarzeń, można postulować dodanie trzeciego elementu - przykładu osobistego wychowawców podejmujących na co dzień trud samowychowania. Wyniki omówionych powyżej badań pozwalają uznać taki postulat za zasadny.

\section{Stosunek młodzieży do samowychowania seksualnego}

W badanej grupie największa część młodzieży przejawiała umiarkowany poziom integracji seksualnej-61,47\%. Niski poziom przejawiało $14,46 \%$ badanych, wysoki $23,85 \%$. Dane te przedstawione zostały w tabeli nr 3 . 


\begin{tabular}{|l|c|c|}
\hline $\begin{array}{c}\text { Poziom integracii } \\
\text { seksualnej młodzieży }\end{array}$ & N & $\%$ \\
\hline Niski & 16 & 14,68 \\
\hline Umiarkowany & 67 & 61,47 \\
\hline Wysoki & 26 & 23,85 \\
\hline
\end{tabular}

Tabela 3.

Struktura poziomu integracii seksualnej młodzieży

Źródło: badania własne

Porównując poziomy integracji seksualnej badanych kobiet i mężczyzn, zauważa się, że niski poziom integracji ponad trzykrotnie częściej wykazywali mężczyźni $(27,77 \%)$ niż kobiety $(8,21 \%)$. Stosunkowo mniej mężczyzn niż kobiet osiągało również umiarkowany i wysoki poziom integracji seksualnej. Dane te są przedstawione w tabeli 4. Wynik ten znajduje swoje uzasadnienie w zróżnicowaniu tempa rozwoju psychoseksualnego mężczyzn i kobiet. Zwykle kobiety wcześniej niż mężczyźni osiągają dojrzałość psychoseksualną ${ }^{19}$.

\begin{tabular}{|l|r|r|c|c|}
\hline \multirow{2}{*}{$\begin{array}{c}\text { Poziom integracii } \\
\text { seksualnei }\end{array}$} & \multicolumn{2}{|c|}{ Kobiety } & \multicolumn{2}{c|}{ Mężczyźni } \\
\cline { 2 - 5 } & $\mathbf{N}$ & $\%$ & $\mathbf{N}$ & $\%$ \\
\hline Niski & 6 & 8,22 & 10 & 27,77 \\
\hline Umiarkowany & 48 & 65,75 & 19 & 52,78 \\
\hline Wysoki & 19 & 26,03 & 7 & 19,45 \\
\hline
\end{tabular}

Tabela 4.

Struktura poziomu integracii seksualnej kobiet i mężczyzn

Źródło: badania własne

Jak zostało zaznaczone, samowychowanie wynika z przyjętych norm, wartości, ideałów. Jego przedmiot, w tym przypadku seksualność, powinien więc $\mathrm{z}$ tymi wartościami korespondować. $\mathrm{W}$ badanej grupie zdania odnośnie do tego, czy wyznawane w życiu wartości i normy moralne powinny dotyczyć seksualności są podzielone. Przekonanych do tego, że te dwie rzeczywistości powinny się łączyć było 60,28\% badanych kobiet i 50\% badanych mężczyzn. Przeciwnego zdania było 20,55\% kobiet i 16,67\% mężczyzn (19,17\% kobiet i 33,33\% mężczyzn nie miało w tej kwestii jednoznacznego zdania). Dane te przedstawia tabela 5 .

19 M. Beisert, Trud dorastania seksualnego, w: Seksualnośc w cyklu życia cztowieka, red. M. Beisert, Warszawa 2011, s. 146-152. 
Tabela 5.

Przekonanie

młodzieży, że wyznawane w życiu

wartości i normy

moralne powinny

dotyczyć

seksualności

\begin{tabular}{|c|c|c|c|c|}
\hline $\begin{array}{l}\text { Przekonanie, że } \\
\text { wyznawane w życiu } \\
\text { wartości i normy } \\
\text { moralne powinny } \\
\text { dołyczyć seksualności }\end{array}$ & Kobiety & & Mężczyźni & \\
\hline & $\mathbf{N}$ & $\%$ & $\mathbf{N}$ & $\%$ \\
\hline Tak & 29 & 39,73 & 9 & 25,00 \\
\hline Raczej tak & 15 & 20,55 & 9 & 25,00 \\
\hline Nie mam zdania & 14 & 19,18 & 12 & 33,33 \\
\hline Raczej nie & 11 & 15,07 & 5 & 13,89 \\
\hline $\mathrm{Nie}$ & 4 & 5,48 & 1 & 2,78 \\
\hline
\end{tabular}

Źródło: badania własne

Jednocześnie jednak większa część badanych, zarówno kobiet $(84,93 \%)$ jak i mężczyzn $(55,55 \%)$ przyznała, że warto ze względu na wyższe cele panować nad własną seksualnością. Wynik ten świadczy o tym, że mimo wszystko seksualność dla znacznej grupy respondentów nie stanowi wartości autonomicznej, samej w sobie, ale jest wpisana w przyjmowaną w życiu hierarchię wartości. Dane te przedstawia tabela 6.

Tabela 6.

Przekonanie młodzieży o ważności

panowania nad własnq seksualnościq ze względu no wyższe cele

\begin{tabular}{|c|c|c|c|c|}
\hline \multirow{2}{*}{$\begin{array}{l}\text { Przekonanie o ważności } \\
\text { panowania nad własną } \\
\text { seksualnościq̨ ze } \\
\text { względu na wyższe cele }\end{array}$} & \multicolumn{2}{|c|}{ Kobiety } & \multicolumn{2}{|c|}{ Mężczyźni } \\
\hline & $\mathbf{N}$ & $\%$ & $\mathbf{N}$ & $\%$ \\
\hline Tak & 42 & 57,53 & 13 & 36,11 \\
\hline Raczej tak & 20 & 27,40 & 7 & 19,44 \\
\hline Nie mam zdania & 2 & 2,74 & 12 & 33,33 \\
\hline Raczej nie & 5 & 6,85 & 1 & 2,78 \\
\hline $\mathrm{Nie}$ & 4 & 5,48 & 3 & 8,33 \\
\hline
\end{tabular}

Źródło: badania własne

Pewien dysonans w odpowiedziach badanych pojawia się w kwestii angażowania wartości i norm etycznych w dziedzinę seksualności. Znaczna część respondentów (por. tabela 6) żywiła przekonanie, że 
warto świadomie kierować własną seksualnością uwzględniając tzw. wyższe cele. Zdania dotyczące jednak tego, czy działania seksualne podlegają ocenie moralnej były wśród badanych podzielone. O ile większość kobiet była przekonana co do tego $(73,98 \%)$, o tyle tego samego zdania było znaczniej mniej mężczyzn (41,67\%). Prawie połowa $(41,76 \%)$ mężczyzn nie miała w tym względzie jednoznacznego przekonania. Być może przyczyną takiego stanu rzeczy jest gotowość młodzieży do realizacji wartości, które sama wybierze i uzna za ważne we własnym życiu, oraz niechęć, jaką żywi do realizacji wartości odgórnie narzuconych, np. wynikających z nauczania Kościoła. Jeśli ta hipoteza byłaby prawdziwa, wskazywałoby to na większe znaczenie dla młodzieży samowychowania w kwestii seksualności niż wychowania.

O tym, że samowychowanie $w$ sprawach seksualnych jest potrzebne, przekonanych było $67,39 \%$ kobiet oraz $66,61 \%$ mężczyzn. Interesujące jest w perspektywie wyników dotyczących humanizacji seksualności, w których to mężczyźni częściej przejawiali mniej dojrzałe przekonania niż kobiety, że w grupie osób przekonanych, iż samowychowanie seksualne nie jest potrzebne, znajdują się wyłącznie kobiety (stanowią 8,45\%). Dane te są przedstawione w tabeli 7 .

\begin{tabular}{|c|c|c|c|c|}
\hline \multirow{2}{*}{$\begin{array}{c}\text { Przekonanie o potrzebie } \\
\text { podejmowania } \\
\text { samowychowania seksualnego }\end{array}$} & \multicolumn{2}{|c|}{ Kobiety } & \multicolumn{2}{|c|}{ Mężczyźni } \\
\hline & $\mathbf{N}$ & $\%$ & $\mathbf{N}$ & $\%$ \\
\hline Tak & 27 & 36,99 & 10 & 27,78 \\
\hline Raczej tak & 22 & 30,14 & 14 & 38,89 \\
\hline Nie mam zdania & 18 & 24,66 & 12 & 33,33 \\
\hline Raczej nie & 4 & 5,48 & 0 & 0,00 \\
\hline $\mathrm{Nie}$ & 2 & 2,74 & 0 & 0,00 \\
\hline
\end{tabular}

Tabela 7.

Przekonanie młodzieży o potrzebie podejmowania samowychowania seksualnego

Źródło: badania własne

Jednocześnie interesujące wydaje się, że więcej kobiet zadeklarowało, iż podejmuje samowychowanie $(83,56 \%)$ niż tych, które żywily przekonanie, że jest to potrzebna w życiu aktywność $(67,39 \%)$. W przypadku mężczyzn proporcje te były wyrównane, przy czym mniej mężczyzn $(63,89 \%)$ niż kobiet $(83,56 \%)$ zadeklarowało, że podejmuje samowychowanie seksualne. Dane te przedstawione są w tabeli 8. 


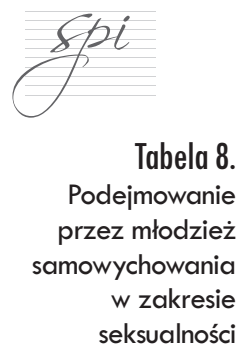

\begin{tabular}{|l|c|c|c|c|}
\hline \multirow{2}{*}{$\begin{array}{c}\text { Podejmowanie } \\
\text { samowychowania } \\
\text { w zakresie seksualności }\end{array}$} & N & $\%$ & N & $\%$ \\
\cline { 2 - 5 } & 41 & 56,16 & 12 & 33,33 \\
\hline Tak & 20 & 27,40 & 11 & 30,56 \\
\hline Raczej tak & 10 & 13,70 & 10 & 27,78 \\
\hline Trudno powiedzieć & 1 & 1,37 & 3 & 8,33 \\
\hline Raczej nie & 1 & 1,37 & 0 & 0,00 \\
\hline Nie & & & & \multicolumn{2}{|c|}{ Mężczyźni } \\
\hline
\end{tabular}

Źródło: badania własne

\section{Wybrane formy samowychowania seksualnego}

Można wyróżnić formy samowychowania, które wydają się szczególnie pożądane w odniesieniu do sfery seksualnej człowieka. Pierwszą z nich jest samokontrola służąca doskonaleniu stosunków międzyludzkich. W jej ramach młodzież może kontrolować własne zachowania (postępowanie, mówienie, myślenie, przeżywanie) lub określone komponenty postaw wobec innych, szczególnie rówieśników. Przykładem takiej samokontroli może być opanowywanie gniewu czy przezwyciężanie złych przyzwyczajeń. Ta forma samowychowania jest wyrazem walki z brakami charakteru i zachowania ${ }^{20}$. W tym kontekście młody człowiek może się uczyć cierpliwości, łagodności postępowania wobec innych, respektowania ich praw, szacunku dla odmiennych poglądów. W kontekście samowychowania seksualnego są to cenne działania, które służą budowaniu dojrzałych i odpowiedzialnych relacji z innymi ludźmi i przeciwdziałają przedmiotowemu odniesieniu do nich.

Drugą formą samowychowania, którą można stosować w odniesieniu do seksualności, są działania służące doskonaleniu charakteru i woli. Polegają one na dostosowywaniu swojego zachowania do przyjętych norm i standardów ${ }^{21}$. W przypadku seksualności ta forma samowychowania jest szczególnie istotna z tego względu, że dopiero integrująca się seksualność młodego człowieka wymaga świadomego

20 A.J. Sowiński, Samowychowanie w interpretacji pedagogicznej, dz. cyt. s. 66-67.

21 Tamże, s. 67. 
kierowania tą sferą życia zgodnie z przyjętymi wartościami, nie zaś poddawania zachowania jedynie kierownictwu naturalnych popędów. Konieczne jest więc najpierw przyjęcie osobistej filozofii życia, a następnie kierowanie zgodnie $\mathrm{z}$ nią własnym postępowaniem.

Trzecią formą samowychowania, przydatną przynajmniej dla niektórych młodych osób, jest podejmowanie wysiłków zmierzających do uwolnienia się od złych przyzwyczajeń ${ }^{22}$. Niekiedy młode osoby mają świadomość szkodliwości podejmowanych aktywności, jednak jest im trudno zaniechać ich podejmowania. Niezależnie od przyczyn tych trudności, możliwe jest podejmowanie takiej aktywności samowychowawczej w zakresie seksualności, która będzie prowadziła do niepodejmowania działań, które nie służą dobru człowieka. Przykładem zachowań związanych ze sferą seksualną, które mogą podlegać działalności samowychowawczej w tym kontekście, jest nałogowe masturbowanie się, korzystanie z pornografii czy podejmowanie ryzykownych zachowań seksualnych.

Środowisko społeczne, w którym dorasta młody człowiek, jest ważnym czynnikiem oddziaływującym na jego rozwój, w tym rozwój seksualny. Kiedy środowisko to nie jest sprzyjające, można podjąć wysiłki samowychowawcze, których celem jest podniesienie standardu warunków ogólnego rozwoju. Chodzi tu o poszukiwanie przez młodzież korzystnych warunków do własnego rozwoju. Drogą do tego może być zmiana otoczenia, zerwanie określonych kontaktów towarzyskich, nawiązanie nowych relacji czy wstąpienie do nowych grup $^{23}$. Przykładowo, jeśli grupa rówieśnicza młodego człowieka wywiera presję, aby podjąć określoną aktywność seksualną, działanie samowychowawcze będzie tu polegało na zaangażowaniu się $\mathrm{w}$ inną grupę rówieśniczą lub tematyczną, taką, która będzie stwarzała lepsze warunki do rozwoju seksualnego. Przykładem są popularne w USA, a także w coraz większym stopniu w Polsce, młodzieżowe grupy związane $z$ wychowaniem do abstynencji seksualnej. Zrzeszają one młode osoby, dla których ważna jest idea wstrzemię́liwości seksualnej przed zawarciem małżeństwa.

$Z$ pewnością przytoczone formy samowychowania seksualnego nie wyczerpują wszystkich możliwych aktywności w tym zakresie,

22 Tamże, s. 68.

23 Tamże, s. 68-69. 
a stanowią jedynie ich egzemplifikację $e^{24}$.Jednak przykłady te pokazują, że formowanie seksualności jest możliwe i służy nie tylko osobie, która ją podejmuje, ale również osobom, z którymi ona pozostaje w relacjach.

\section{Formacja młodzieży a samowychowanie seksualne}

Wydaje się, że współczesna rzeczywistość społeczna stwarza pewne zagrożenie w postaci redukcyjnego odniesienia do człowieka, w tym także w kontekście jego seksualności. Formacja człowieka jako taka powinna obejmować całą osobę, choć mówi się o formacji poszczególnych sfer życia człowieka, np. formacji intelektualnej. Procesy te pozornie tylko odnoszą się do jednego wymiaru życia człowieka - intelektu czy osobowości. Formacja bowiem jednego aspektu służy całej osobie. Podobnie rzecz ma się w przypadku seksualności. Samowychowanie seksualne w żadnej mierze nie ogranicza się do formowania tylko seksualności. Samowychowanie seksualne stanowić ma wkład w rozwój człowieka w jego osobowym, najpełniejszym wymiarze. Jako takie, samowychowanie seksualne obejmuje swoim zasięgiem wysiłek kształtowania woli, charakteru, emocji, moralności, intelektualne poznawanie czy też pobudzanie w sobie postaw prospołecznych. Można więc powiedzieć, że samowychowanie seksualne może przebiegać dwukierunkowo. Pierwszym kierunkiem jest kształtowanie seksualności w odniesieniu do innych sfer życia człowieka (jego emocji, relacji, reaktywności, moralności itp.). Punktem wyjścia jest seksualność, a samowychowanie polegać ma na włączaniu jej w całość życia człowieka i odnoszeniu jej do innych sfer funkcjonowania osoby. W drugim kierunku punktem wyjścia mogą być różnorodne płaszczyzny życia, które są przedmiotem samowychowania (np. intelekt, moralność, relacje), a w ramach ich doskonalenia szczegółową uwagę poświęca się wychowywaniu własnej seksualności.

Jak zostało powyżej zaznaczone, celem samowychowania seksualnego jest dążenie do integracji seksualnej, a więc osiągnięcia takiego stanu, w którym seksualność harmonijnie współdziała ze wszystkimi innymi sferami życia. Można więc przyjąć, że samowychowanie seksualne w szerokim sensie ma za swój cel (auto)formację osoby jako

24 Oprócz form samowychowania w literaturze przedmiotu wymienia się jego metody i techniki, np. metodę samoobserwacji, autorefleksji - samoanalizy, autowerbalizacji przeżyć i doświadczeń czy też metodę stawiania siebie w sytuacji wyboru. Zob. A.J. Sowiński, Samowychowanie w interpretacji pedagogicznej, dz. cyt., s. 70-71. 
takiej, by w efekcie podejmowanych wysiłków wzrastała ona w człowieczeństwie, a jej działania miały w pełni osobowy charakter. Przyjęcie tezy, że samowychowanie seksualne jest ważnym elementem formacji młodego człowieka wydaje się w tym kontekście uzasadnione. Jeśli ponadto uwzględni się dokonujące się społeczno-kulturowe zmiany, w obliczu których dorasta współcześnie młodzież, potrzeba formacji młodych osób i pobudzania ich do samowychowania seksualnego wydaje się stanowić ważny obszar działalności wychowawczej.

\section{Zakończenie}

Samowychowanie seksualne stanowi szczegółowy rodzaj samowychowania jako takiego. Warunkiem wstępnym podjęcia tej aktywności jest uznanie złożonej, wielowymiarowej istoty seksualności człowieka. Celem samowychowania seksualnego jest osiągnięcie integracji seksualnej. Jak wynika z przeprowadzonych badań, rola rodziców w tym zakresie nie jest bez znaczenia. Większa część badanej młodzieży deklaruje, że podejmuje aktywność samowychowawczą w zakresie seksualności, choć w grupie tej zaznaczają się pewne różnice. W literaturze przedmiotu można nadto można wyróżnić formy i metody samowychowania, które wydają się być szczególnie przydatne w przypadku samowychowania seksualnego. Ostatecznie można w myśl przytoczonych refleksji uznać, że samowychowanie seksualne stanowi istotny element formacji młodego człowieka.

Ze względu na specyfikę przedmiotu samowychowania seksualnego, intymny i najbardziej osobisty wymiar tej sfery życia, właściwie nie jest możliwe, żeby jakiekolwiek inne oddziaływania mogły tę aktywność własną człowieka zastąpić lub zrekompensować jej brak. Możliwe jest jednak wspieranie człowieka od najwcześniejszych lat życia na drodze ku podejmowaniu w coraz większym zakresie wysiłku samowychowania, w tym samowychowania seksualnego.

\section{Bibliografia}

Bancroft J., Seksualnośćcztorwieka, ttum. R. Śmietana, Elsevier Urban \& Partner, Wrocław 2011.

Beisert M., Trud dorastania seksualnego, w: Seksualnośc w cyklu życia cztowieka, red.

M. Beisert, Wydawnictwo Naukowe PWN, Warszawa 2011, s. 145-170. 
Chlewiński Z., Seks i autorealizacja (1), „W Drodze” 1978, t. 6, nr 2(54), s. $13-20$.

Franciszek, Posynodalna adhortacja apostolska „Amoris laetitia”, Wydawnictwo św. Stanisława BM, Kraków 2016.

Izdebski Z., Seksualnośc Polaków na poczq̨tku XXI wieku. Studium badawcze, Wydawnictwo UJ, Kraków 2012.

Laphimon M., A Glossary of Terms in Gender and Sexuality, The Rockefeller Foundation - Mahidol University Thailand, Seul 2005.

Lew-Starowicz Z., Seksuologia psychospoteczna, w: Podstawy seksuologii, red. Z. Lew-Starowicz, V. Skrzypulec, Wydawnictwo Lekarskie PZWL, Warszawa 2010, s. 25-33.

Matulka Z., Samowychowanie, w: Wprowadzenie do pedagogiki dorostych, red. T. Wujek, Wydawnictwo Naukowe PWN, Warszawa 1992, s. 147-157.

Okoń W., Nowy stownik pedagogiczny, Wydawnictwo Akademickie „Żak”, Warszawa 2007.

Podstawa programowa przedmiotu Wychowanie do życia $\mathrm{w}$ rodzinie. II etap edukacyjny: klasy IV-VI, <https://men.gov.pl/wp-content/ uploads/2011/02/4i.pdf> [dostęp: 9.10.2016].

Reber A.S., Reber E.S., Stownik psychologii, tłum. B. Janasiewicz-Kruszyńska, Scholar, Warszawa 2000.

Rojewska E., Personalistyczna orientacja wychowawcza rodziców a integracja seksualna mtodzieży. Badania empiryczne, niepublikowana rozprawa doktorska napisana pod kierunkiem prof. dr hab. Zdzisława Kroplewskiego, Szczecin 2016.

Smołka E., Filozofia ksztattowania charakteru. Fryderyka Wilhelma Foerstera teoria wychowania w świetle zatożen personalizmu chrześcijańskiego, Wydawnictwo Maternus Media, Tychy 2005.

Sowiński A.J., Rozważania o samowychowaniu, Oficyna In Plus, Szczecin 1997.

Sowiński A.J., Samowychowanie w interpretacji pedagogicznej, Oficyna In Plus, Szczecin 2006.

Sowiński A.J., Samowychowawcza aktywność mtodzieży, Wydawnictwo Naukowe US, Szczecin 1990.

\section{ADRES DO KORESPONDENCJI:}

Dr Ewa Rojewska

Uniwersytet Szczeciński

Wydział Teologiczny

ewa.rojewska@usz.edu.pl 